\title{
PEMODELAN REGRESI ROBUST S-ESTIMATOR UNTUK PENANGANAN PENCILAN MENGGUNAKAN GUI MATLAB (Studi Kasus : Faktor-Faktor yang Mempengaruhi Produksi Ikan Tangkap di Jawa Tengah) \\ Dhea Kurnia Mubyarjati ${ }^{1}$, Abdul Hoyyi ${ }^{2}$, Hasbi Yasin ${ }^{3}$ \\ 1,2,3 Departemen Statistika FSM Universitas Diponegoro e-mail : dheakurniamubyarjati@gmail.com
}

\begin{abstract}
Multiple Linear Regression can be solved by using the Ordinary Least Squares (OLS). Some classic assumptions must be fulfilled namely normality, homoskedasticity, nonmulticollinearity, and non-autocorrelation. However, violations of assumptions can occur due to outliers so the estimator obtained is biased and inefficient. In statistics, robust regression is one of method can be used to deal with outliers. Robust regression has several estimators, one of them is Scale estimator (S-estimator) used in this research. Case for this reasearch is fish production per district / city in Central Java in 2015-2016 which is influenced by the number of fishermen, number of vessels, number of trips, number of fishing units, and number of households / fishing companies. Approximate estimation with the Ordinary Least Squares occur in violation of the assumptions of normality, autocorrelation and homoskedasticity this occurs because there are outliers. Based on the ttest at 5\% significance level can be concluded that several predictor variables there are the number of fishermen, the number of ships, the number of trips and the number of fishing units have a significant effect on the variables of fish production. The influence value of predictor variables to fish production is $88,006 \%$ and MSE value is 7109,519. GUI Matlab is program for robust regression for S-estimator to make it easier for users to do calculations.
\end{abstract}

Keywords: Ordinary Least Squares (OLS), Outliers, Robust Regression, Fish Production, GUI Matlab.

\section{PENDAHULUAN}

Indonesia merupakan negara kepulauan terbesar di dunia. Menurut Farhan Hakim, peneliti dan pemerhati maritim di dalam Hendra \& Amir (2014), Jawa Tengah memiliki potensi maritim yang sangat besar secara geografis. Perikanan tangkap Provinsi Jawa Tengah mempunyai potensi untuk dikembangkan.

Beberapa faktor yang diduga mempengaruhi perikanan tangkap adalah jumlah rumah tangga/perusahaan perikanan, jumlah unit penangkapan, jumlah nelayan, jumlah kapal dan jumlah trip. Agar diketahui faktor yang berpengaruh secara signifikan maka berdasarkan statistik dapat diketahui dengan metode regresi linier berganda menggunakan estimasi parameter Metode Kuadrat Terkecil (MKT).

Pada data produksi ikan tangkap terjadi pelanggaran asumsi normalitas, autokorelasi dan heteroskedastisitas. Salah satu penyebab terjadinya pelanggaran asumsi yaitu adanya pencilan pada data. Menurut Draper dan Smith (1998), adakalanya pencilan memberikan informasi yang tidak bisa diberikan oleh titik data lainnya.

Regresi robust adalah metode yang penting untuk menganalisis data yang terkontaminasi oleh pencilan. Dalam regresi robust terdapat beberapa metode estimasi seperti estimasi Least Median Of Squares (LMS), estimasi Maximum Likelihood type (M), estimasi Least Trimmed Square (LTS), estimasi Scale (S), estimasi Method Of Moment (MM) (Chen, 2002). 
Penelitian ini dilakukan uuntuk menganalisis data produksi ikan tangkap di Jawa Tengah menggunakan regresi robust S-estimator dengan menerapkan GUI Matlab. Penerapan GUI Matlab dilakukan agar mempermudah dalam perhitungan regresi robust $S$ estimator.

\section{TINJAUAN PUSTAKA}

\subsection{Perikanan Tangkap}

Berdasarkan Dinas Kelautan dan Perikanan Provinsi Jawa Tengah produksi perikanan tangkap dipengaruhi oleh beberapa faktor, diantaranya jumlah nelayan, jumlah kapal, jumlah trip, jumlah unit penangkapan, dan jumlah rumah tangga atau perusahaan perikanan.

\subsubsection{Jumlah nelayan}

Jumlah nelayan merupakan orang yang aktif melakukan pekerjaan dalam operasi penangkapan ikan atau binatang air atau tanaman air, orang yang ahli dalam mesin dan juru masak.

\subsubsection{Jumlah kapal}

Perahu atau kapal yang langsung digunakan dalam operasi penangkapan ikan atau binatang air atau tanaman air. Kapal pengangkut tidak sama dengan kapal yang dimaksud.

\subsubsection{Jumlah trip}

Kegiatan operasi penangkapan ikan sejak unit penangkapan ikan meninggalkan pangkalan menuju daerah operasi, mencari daerah penangkapan ikan, melakukan penangkapan ikan, sampai kembali lagi ke tempat pangkalam asal atau ke tempat pendaratan lain.

\subsubsection{Jumlah unit penangkapan}

Kesatuan teknis dalam suatu operasi penangkapan yang biasanya terdiri dari kapal penangkap ikan dan alat penangkapan ikan yang digunakan.

\subsubsection{Jumlah rumah tangga atau perusahaan perikanan}

Rumah tangga perikanan merupakan rumah tangga yang melakukan kegiatan penangkapan ikan atau binatang air atau tanaman air dengan tujuan untuk dijual. Sedangkan perusahaan perikanan adalah unit ekonomi berbadan hukum yang melakukan kegiatan penangkapan ikan atau binatang air atau tanaman air dengan tujuan hasil dari penangkapan tersebut dijual.

\subsection{Regresi Linier Berganda}

Menurut Montgomery dan Runger (2003), persamaan dari model regresi berganda dapat dinyatakan sebagai berikut :

$$
y_{i}=\beta_{0}+\beta_{1} x_{i 1}+\beta_{2} x_{i 2}+\cdots+\beta_{k} x_{i k}+\varepsilon_{i}
$$

Persamaan (1) ditulis dalam bentuk matriks, maka dapat ditulis sebagai berikut:

\subsubsection{Estimasi Parameter Model}

$$
\begin{aligned}
& {\left[\begin{array}{c}
y_{1} \\
y_{2} \\
\vdots \\
y_{n}
\end{array}\right]=\left[\begin{array}{ccccc}
1 & x_{11} & x_{12} & \cdots & x_{1 k} \\
1 & x_{21} & x_{22} & \cdots & x_{2 k} \\
1 & \vdots & \vdots & \ddots & \vdots \\
1 & x_{n 1} & x_{n 2} & \cdots & x_{n k}
\end{array}\right]\left[\begin{array}{c}
\beta_{0} \\
\beta_{1} \\
\vdots \\
\beta_{k}
\end{array}\right]+\left[\begin{array}{c}
\varepsilon_{1} \\
\varepsilon_{2} \\
\vdots \\
\varepsilon_{k}
\end{array}\right]} \\
& \begin{array}{llll}
\boldsymbol{y} & \boldsymbol{X} & \boldsymbol{\beta} & +\varepsilon
\end{array}
\end{aligned}
$$

Menurut Gujarati (2004), metode Kuadrat Terkecil (MKT) atau Ordinary Least Square (OLS) digunakan untuk mengestimasi parameter model regresi adalah dengan meminimumkan jumlah kuadrat error.

$$
L=\sum_{i=1}^{n} \varepsilon_{i}^{2}=\varepsilon^{T} \varepsilon=(y-X \beta)^{T}(y-X \beta)
$$

Meminimumkan $\boldsymbol{L}$ untuk mendapatkan estimator metode kuadrat terkecil harus memenuhi $\left.\frac{\partial L}{\partial \beta}\right|_{\beta=\widehat{\beta}}=\frac{\partial \sum_{i=1}^{n} \varepsilon_{i}^{2}}{\partial \boldsymbol{\beta}}=\frac{\partial \varepsilon^{T} \varepsilon}{\partial \boldsymbol{\beta}}=-2 X^{T} y+2 X^{T} X \widehat{\beta}=0$ 
karena $\left.\frac{\partial L}{\partial \boldsymbol{\beta}}\right|_{\boldsymbol{\beta}=\widehat{\boldsymbol{\beta}}}=0$, maka $-\mathbf{2} \boldsymbol{X}^{\boldsymbol{T}} \boldsymbol{y}+\mathbf{2} \boldsymbol{X}^{\boldsymbol{T}} \boldsymbol{X} \widehat{\boldsymbol{\beta}}=0$, sehingga

\subsubsection{Uji Hipotesis}

$$
\widehat{\beta}=\left(X^{T} X\right)^{-1} X^{T} y
$$

\section{Uji F (Uji Kecocokan Model)}

Menurut Montgomery and Peck (1992), uji kecocokan model digunakan untuk menguji signifikansi regresi jika ada hubungan linier antara variabel respon $y$ dan variabel prediktor $x_{1}, x_{2}, \ldots, x_{k}$ secara bersama-sama. Langkah-langkahnya sebagai berikut :

a. Hipotesis

$\mathrm{H}_{0}: \beta_{1}=\beta_{2}=\ldots=\beta_{\mathrm{k}}=0$ (tidak terdapat hubungan antara variabel respon $y$ dengan variabel prediktor $x_{j}$ secara bersama-sama)

$\mathrm{H}_{1}$ : terdapat $\beta_{\mathrm{j}} \neq 0$, dengan $\mathrm{j}=1,2, \ldots, \mathrm{k}$ (terdapat hubungan antara variabel respon $y$ dengan variabel prediktor $x_{j}$ secara bersama-sama)

b. Statistik uji

$$
F_{\text {hitung }}=\frac{S S_{R} / k}{S S_{E} /(n-k-1)}=\frac{\mathrm{MSR}}{\mathrm{MSE}}
$$

c. Kriteria uji

$$
\mathrm{H}_{0} \text { ditolak jika } F_{\text {hitung }}>F_{(\alpha, k, n-k-1)} \text { atau } p \text {-value }<\alpha
$$

\section{Uji t (Uji Koefisien Regresi secara Individual)}

Uji t digunakan untuk menguji ada tidaknya pengaruh yang signifikan antara masing - masing variabel prediktor terhadap model regresi linier. Langkah-langkah analisisnya sebagai berikut:

a. Hipotesis

$\mathrm{H}_{0}: \beta_{\mathrm{j}}=0$ (koefisien parameter variabel $x_{j}$ tidak signifikan terhadap $y$ )

$\mathrm{H}_{1}: \beta_{\mathrm{j}} \neq 0$, (koefisien parameter variabel $x_{j}$ signifikan terhadap $y$ )

b. Statistik uji

Menurut Montgomery dan Peck (1992), rumus $t_{\text {hitung }}$ adalah :

$t=\frac{\widehat{\beta}_{j}}{\operatorname{Se}\left(\widehat{\beta}_{j}\right)}$

c. Kriteria uji

$$
\mathrm{H}_{0} \text { ditolak jika }\left|t_{\text {hitung }}\right|>t_{(\alpha / 2, n-k-1)} \text { atau } p \text {-value }<\alpha
$$

\subsubsection{Goodness of Fit}

\section{1. $\quad$ Adjusted $R^{2}$}

Menurut Gujarati (2004), pada model regresi berganda $R^{2}$ digunakan untuk mengetahui proporsi variasi dalam $y$ yang dijelaskan beberapa variabel $x$ secara bersamasama.

\section{MSE}

$$
R^{2}{ }_{A d j, k}=1-\frac{S S_{E} /(n-k-1)}{S S_{T} /(n-1)}=1-\frac{(n-1)}{(n-k-1)}\left(1-R^{2}\right)
$$

Menurut Montgomery dan Peck (1992), Mean Squared Error digunakan untuk merujuk pada estimasi tak bias variansi error dimana jumlah kuadrat residual dibagi dengan derajat kebebasan (n-k-1). Rumus MSE dinyatakan sebagai berikut :

$$
M S E=\frac{S S_{E}}{n-k-1}
$$




\subsubsection{Uji Asumsi}

\section{Normalitas}

Gujarati (2004) menjelaskan bahwa pada regresi linear klasik diasumsikan bahwa tiap $\varepsilon_{i}$ didistribusikan normal dengan $\varepsilon_{i} \sim N\left(0, \sigma^{2}\right)$. Salah satu uji formal yang dapat digunakan untuk menguji asumsi kenormalan suatu data adalah uji Liliefors.

$$
D=\sup _{z}\left|F_{0}(z)-S(z)\right|
$$

\section{Multikolinearitas}

Deteksi multikolinieritas untuk menguji adanya korelasi antar variabel prediktor pada model regresi yang terbentuk. Salah satu cara untuk mengetahui adanya multikolinieritas, yaitu harga VIF (Variance Inflation Factors) yang menurut Montgomery dan Peck (1992), didefinisikan dengan rumus :

$$
\operatorname{VIF}\left(x_{j}\right)=\frac{1}{\left(1-R_{j}^{2}\right)}, \mathrm{i}=1,2, \ldots, \mathrm{n}
$$

Nilai VIF >10 menunjukkan multikolinearitas yang kuat (Montgomery dan Peck, 1992).

\section{Autokorelasi}

Model regresi linier klasik mengasumsikan bahwa error yang berhubungan dengan pengamatan tidak dipengaruhi oleh error yang berhubungan dengan pengamatan lain manapun. Non-autokorelasi ditulis dengan lambang: $E\left(\varepsilon_{i} \varepsilon_{j}\right)=0 \quad i \neq j$. Salah satu cara yang dapat digunakan untuk mendeteksi autokorelasi adalah dengan uji Durbin Watson.

$$
d=\frac{\sum_{i=2}^{i=n}\left(e_{i}-e_{i-1}\right)^{2}}{\sum_{i=1}^{i=n} e_{i}^{2}}
$$

\section{Heteroskedastisitas}

Tujuan dari uji Heteroskedastisitas adalah mengetahui apakah terjadi variansi error satu pengamatan ke pengamatan yang lain, konstan atau tidak dalam model regresi. Lambang homoskedastisitas adalah : $E\left(\varepsilon_{i}^{2}\right)=\sigma^{2} \quad i=1,2, \ldots, n$.

Menurut Gujarati (2004), heteroskedastisitas dapat diperiksa dengan menggunakan uji Glejser. Uji Glejser dilakukan dengan meregresikan nilai absolut dari $e_{i}\left(\left|e_{i}\right|\right)$ terhadap variabel-variabel prediktor yang diperkirakan mempunyai hubungan erat dengan $\sigma_{i}^{2}$.

$$
\left|e_{i}\right|=\beta_{0}+\beta_{1} x_{i 1}+\beta_{2} x_{i 2}+\cdots+\beta_{k} x_{i k}+\varepsilon_{i}
$$

\subsection{Pendeteksian Pencilan}

Montgomery dan Peck (1992) pencilan adalah suatu pengamatan yang ekstrim. Uji DFFITS (Difference in Fit Standardized) merupakan salah satu metode yang digunakan untuk mengidentifikasi adanya pencilan. Rumus $\operatorname{DFFITS}_{i}$ didefinisikan:

$$
\left(\text { DFFITS }_{i}\right)=t_{i}\left(\frac{h_{i i}}{1-h_{i i}}\right)^{\frac{1}{2}}
$$

dimana $t_{i}$ adalah R-student (studentized deleted residual) untuk kasus ke-i dengan rumus:

$$
t_{i}=e_{i} \sqrt{\frac{n-p-1}{S S_{E}\left(1-h_{i i}\right)-e_{i}^{2}}}
$$

Disebut pencilan jika nilai $|D F F I T S|>1$ untuk data yang berukuran kecil sampai sedang dan nilai $\mid$ DFFITS $\mid>2 \sqrt{p / n}$ untuk data yang berukuran besar, dengan $p=k+1$ dan $n$ adalah banyaknya observasi (Neter, 1997).

\subsection{Fungsi Objektif}

Fungsi yang digunakan untuk mencari fungsi pembobot pada regresi robust adalah fungsi obyektif (Fox, 2002). 
Tabel 1. Fungsi Obyektif, Fungsi Pengaruh dan Fungsi Pembobot Estimasi Kuadrat Terkecil dan Tukey Bisquare

\begin{tabular}{|c|c|c|}
\hline Metode & Kuadrat Terkecil & Tukey Bisquare \\
\hline Fungsi Obyektif & $\begin{array}{l}\rho\left(u_{i}\right)=\frac{1}{2} u_{i}^{2} \\
, \text { untuk }\left|u_{i}\right|<\infty\end{array}$ & $\begin{array}{l}\rho\left(u_{i}\right) \\
= \begin{cases}\frac{c^{2}}{6}\left\{1-\left[1-\left(\frac{u_{i}}{c}\right)^{2}\right]^{3}\right\} & , \text { untuk }\left|u_{i}\right| \leq c \\
\frac{c^{2}}{6} & , \text { untuk }\left|u_{i}\right|>c\end{cases} \end{array}$ \\
\hline $\begin{array}{l}\text { Fungsi } \\
\text { Pengaruh } \\
{\left[\psi\left(u_{i}\right)=\frac{\partial\left(\rho\left(u_{i}\right)\right)}{\partial\left(u_{i}\right)}\right]}\end{array}$ & $\begin{array}{l}\psi\left(u_{i}\right)=u_{i} \\
\text {, untuk }\left|u_{i}\right|<\infty\end{array}$ & $\psi\left(u_{i}\right)=\left\{\begin{array}{cl}u_{i}\left[1-\left(\frac{u_{i}}{c}\right)^{2}\right]^{2} & , \text { untuk }\left|u_{i}\right| \leq c \\
0 & , \text { untuk }\left|u_{i}\right|>c\end{array}\right.$ \\
\hline $\begin{array}{l}\text { Fungsi } \\
\text { Pembobot } \\
{\left[w\left(u_{i}\right)=\frac{\psi\left(u_{i}\right)}{u_{i}}\right]}\end{array}$ & $\begin{array}{l}w\left(u_{i}\right)=1 \\
, \text { untuk }\left|u_{i}\right|<\infty\end{array}$ & $w\left(u_{i}\right)=\left\{\begin{array}{cl}{\left[1-\left(\frac{u_{i}}{c}\right)^{2}\right]^{2}} & , \text { untuk }\left|u_{i}\right| \leq c \\
0 & , \text { untuk }\left|u_{i}\right|>c\end{array}\right.$ \\
\hline
\end{tabular}

(Stuart, 2011)

\subsection{Regresi Robust S-estimator}

Rousseeuw dan Leroy (1987) menyatakan bahwa estimasi regresi yang memiliki breakdown point tinggi salah satunya adalah S-estimator yang diperkenalkan oleh Rousseeuw dan Yohai (1984). S-estimator didefinisikan dengan :

$$
\widehat{\boldsymbol{\beta}}=\min _{\boldsymbol{\beta}}\left(e_{1}(\boldsymbol{\beta}), e_{2}(\boldsymbol{\beta}) \ldots, e_{n}(\boldsymbol{\beta})\right)
$$

$e_{i}$ merupakan residual ke- $i$ dari $\boldsymbol{\beta}$ dan $s\left(e_{1}, e_{2} \ldots, e_{n}\right)$ didefinisikan sebagai solusi dari:

$$
\frac{1}{n} \sum_{i=1}^{n} \rho\left(\frac{e_{i}}{s}\right)=\frac{1}{n} \sum_{i=1}^{n} \rho\left(\frac{y_{i}-\sum_{j=0}^{k} x_{i j} \beta_{j}}{s}\right)=K
$$

Untuk mencapai breakdown point 50\%, maka $K=E_{\phi} \rho\left(u_{i}\right)=0.1995$ dan $c=1.547$ (Rousseeuw dan Yohai, 1984). Menurut Maronna, Martin dan Yohai (2006) :

$$
s=\sqrt{\frac{1}{n K} \sum_{i=1}^{n} w_{i} e_{i}^{2}}
$$

Pembobot $w_{i}=w\left(u_{i}\right)=\frac{\rho\left(u_{i}\right)}{u_{i}{ }^{2}} \quad$ untuk iterasi berikutnya. Untuk iterasi pertama menggunakan :

$$
s=\frac{M A D}{0,6745}=\frac{\text { median } \mid e_{i}-\text { median }\left(e_{i}\right) \mid}{0,6745}
$$

dengan menurunan parsial pertama dari $\rho$ terhadap $\beta_{j}(j=0,1, \ldots, k)$ disamakan dengan 0 , sehingga:

$$
\sum_{i=1}^{n} x_{i j} \psi\left(\frac{y_{i}-\sum_{j=0}^{k} x_{i j} \beta_{j}}{s}\right)=0, \quad j=0,1, \ldots, k
$$

Draper dan Smith (1998) memberikan solusi dengan mendefinisikan fungsi pembobot :

$$
w\left(u_{i}\right)=\frac{\psi\left(\frac{y_{i}-\sum_{j=0}^{k} x_{i j} \beta_{j}}{s}\right)}{\left(\frac{y_{i}-\sum_{j=0}^{k} x_{i j} \beta_{j}}{s}\right)}
$$

dan $w_{i}=w\left(u_{i}\right)$. Kemudian estimasi persamaan (17) dapat ditulis:

$$
\sum_{i=1}^{n} x_{i j} w_{i}\left(y_{i}-\sum_{j=0}^{k} x_{i j} \beta_{j}\right)=0 \quad, j=0,1, \ldots, k
$$

Persamaan (20) diselesaikan dengan Iteratively Reweighted Least Square (IRLS). Pada notasi matrik, persamaan (20) dapat ditulis: 


$$
\widehat{\boldsymbol{\beta}}_{j}=\left(\boldsymbol{X}^{\prime} \boldsymbol{W} \boldsymbol{X}\right)^{-1} \boldsymbol{X}^{\prime} \boldsymbol{W} \mathbf{y}
$$

Iterasi akan berhenti jika $\widehat{\boldsymbol{\beta}}_{\boldsymbol{j}}$ konvergen yaitu selisih nilai $\widehat{\boldsymbol{\beta}}_{\boldsymbol{j}}^{(\boldsymbol{m}+\mathbf{1})}$ dan $\widehat{\boldsymbol{\beta}}_{\boldsymbol{j}}^{(\boldsymbol{m})}$ mendekati 0 .

\subsection{Graphical User Interface (GUI)}

Matlab merupakan sebuah singkatan dari Matrix Laboratory. Menurut Pusadan (2014), GUI pada Matlab merupakan sebuah aplikasi display dari Matlab yang mengandung tugas, perintah, atau komponen program yang mempermudah user atau pengguna dalam menjalankan sebuah program dalam Matlab.

\section{METODE PENELITIAN}

\subsection{Jenis dan Sumber Data}

Penelitian ini menggunakan data sekunder yaitu data produksi ikan, jumlah rumah tangga/perusahaan perikanan, jumlah unit penangkapan, jumlah nelayan, jumlah kapal dan jumlah trip dari setiap kabupaten/kota di Jawa Tengah tahun 2015 sampai 2016. Data ini didapat langsung dari Dinas Kelautan dan Perikanan Provinsi Jawa Tengah dan Badan Pusat Statistik Jawa Tengah.

\subsection{Variabel Penelitian}

Variabel yang digunakan pada penelitian ini terdiri dari variabel respon dan variabel prediktor. Variabel-variabel tersebut sebagai berikut:

$\begin{array}{llll}y & \text { : Produksi Ikan } & x_{3} & \text { : Jumlah trip } \\ x_{1} & \text { : Jumlah nelayan } & x_{4} & \text { : Jumlah unit penangkapan } \\ x_{2} & \text { : Jumlah kapal } & x_{5} & \text { : Jumlah rumah tangga/perusahaan perikanan }\end{array}$

\subsection{Metode Analisis Data}

Software statistik yang digunakan adalah Matlab R2015b. Langkah-langkah analisis untuk mendapatkan model regresi robust S-estimator sebagai berikut:

1. Mengestimasi koefisien regresi menggunakan Metode Kuadrat Terkecil

2. Melakukan uji $\mathrm{F}$ dan uji koefisien regresi secara individual (uji t).

3. Menghitung koefisien determinasi yang disesuaikan (Adjusted $R^{2}$ ) dan MSE.

4. Melakukan uji asumsi regresi liner berganda.

5. Melakukan pendeteksian pencilan dengan DFFITS $_{i}$.

6. Melakukan estimasi parameter dengan regresi robust S-estimator. Menurut Maronna, Martin dan Yohai (2006); Susanti, et al (2014), prosedurnya sebagai berikut:

1) Menghitung nilai residual $e_{i}=y_{i}-\hat{y}_{i}$

2) Menghitung

$$
s= \begin{cases}\frac{\text { median } \mid e_{i}-\text { median }\left(e_{i}\right) \mid}{0,6745} & , \text { iterasi pertama } \\ \sqrt{\frac{1}{n K} \sum_{i=1}^{n} w_{i} e_{i}{ }^{2}} & , \text { iterasi berikutnya }\end{cases}
$$

dengan $K=0,1995$

3) Menghitung nilai $u_{i}=\frac{e_{i}}{s}$

4) Menentukan nilai pembobot $w_{i}$ (metode Tukey Bisquare):

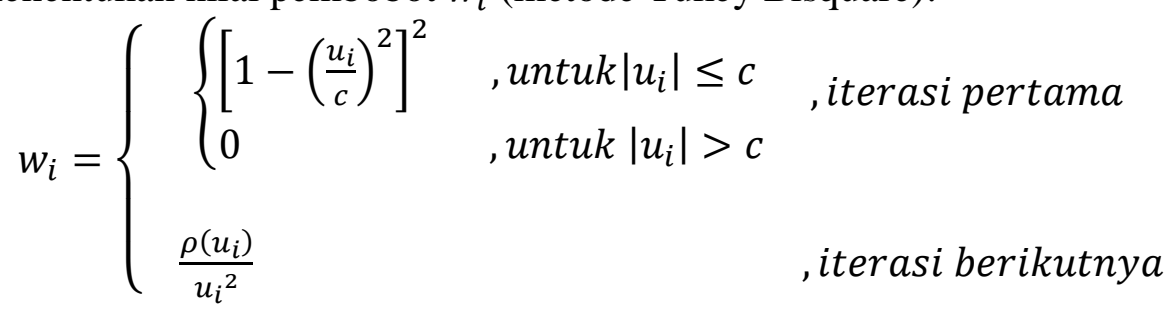


dengan $c=1,547$

5) Menghitung estimasi parameter regresi baru $\left(\hat{\beta}_{j}^{m}\right)$ dengan menggunakan nilai pembobot $w_{i}$.

7. Mengulang langkah a sampai e untuk mendapatkan nilai $\hat{\beta}_{j}$ konvergen.

8. Melakukan uji F dan uji koefisien regresi secara individual (uji t).

9. Menghitung koefisien determinasi yang disesuaikan (Adjusted $R^{2}$ ) dan MSE.

\section{HASIL DAN PEMBAHASAN}

\subsection{Regresi Linier Berganda}

Awal penelitian dilakukan analisis regresi linier berganda dengan estimasi parameter menggunakan Metode Kuadrat Terkecil (MKT).

\subsubsection{Estimasi Parameter Regresi}

Estimasi parameter regresi menggunakan Metode Kuadrat Terkecil didapatkan model sebagai berikut :

$$
\hat{y}=109,9-0,12089 x_{1}+0,088464 x_{2}+0,00175 x_{3}+0,2101 x_{4}+0,00099 x_{5}
$$

\subsubsection{Uji Hipotesis}

\section{Uji F}

\section{a. Hipotesis}

$\mathrm{H}_{0}: \beta_{1}=\beta_{2}=\beta_{3}=\beta_{4}=\beta_{5}=0$

$\mathrm{H}_{1}$ : terdapat $\beta_{\mathrm{j}} \neq 0, \mathrm{j}=1,2,3,4,5$

b. Taraf signifikansi

$$
\alpha=5 \% \cong 0,05
$$

c. Statistik uji

$$
F_{\text {hitung }}=17,061 \text { dan } p \text {-value }=0,00000
$$

\section{d. Kriteria uji}

$\mathrm{H}_{0}$ ditolak jika $F_{\text {hitung }}>\left(F_{(5 \%, 5,52)}=2,39\right)$ atau $p$-value $<\alpha(0,05)$

\section{e. Keputusan}

$\mathrm{H}_{0}$ ditolak karena $p$-value $(0,00000)<\alpha(0,05)$

\section{f. Kesimpulan}

Pada taraf signifikansi 5\% terdapat hubungan antara variabel respon produksi ikan dengan variabel prediktor (jumlah nelayan, jumlah kapal, jumlah trip, jumlah unit penangkapan, dan jumlah rumah tangga/perusahaan perikanan) secara bersama-sama.

2. Uji t
a. Hipotesis
$\mathrm{H}_{0}: \beta_{\mathrm{j}}=0$, dimana $\mathrm{j}=1,2,3,4,5$
$\mathrm{H}_{1}: \beta_{\mathrm{j}} \neq 0$, dimana $\mathrm{j}=1,2,3,4,5$

b. Taraf signifikansi

$\alpha=5 \% \cong 0,05$

c. Statistik uji

Disajikan pada Tabel 2. 
d. Kriteria uji

$\mathrm{H}_{0}$ ditolak jika $\left|t_{\text {hitung }}\right|>\left(t_{(2,5 \%, 52)}=2,00665\right)$ atau $p$-value $<\alpha(0,05)$

e. Keputusan

Tabel 2. Tabel Uji t Regresi Linier Berganda

\begin{tabular}{cccc}
\hline Variabel & $\boldsymbol{t}_{\text {hitung }}$ & $\boldsymbol{p}$-value & Keputusan \\
\hline Constant & 1,3164 & 0,19382 & $\mathrm{H}_{0}$ diterima \\
Jumlah nelayan & $-1,6904$ & 0,09695 & $\mathrm{H}_{0}$ diterima \\
Jumlah kapal & 1,7941 & 0,07861 & $\mathrm{H}_{0}$ \\
Jumlah trip & 6,0801 & 0,00000 & $\mathrm{H}_{0}$ ditolak \\
Jumlah unit penangkapan & 2,8102 & 0,00696 & $\mathrm{H}_{0}$ ditolak \\
$\begin{array}{c}\text { Jumlah rumah } \\
\text { tangga/perusahaan perikanan }\end{array}$ & 1,9479 & 0,05684 & $\mathrm{H}_{0}$ diterima \\
\hline
\end{tabular}

\section{f. Kesimpulan}

Pada taraf signifikansi 5\% koefisien parameter variabel jumlah trip $\left(x_{3}\right)$ dan jumlah unit penangkapan $\left(x_{4}\right)$ berpengaruh signifikan terhadap produksi ikan $(y)$.

\subsubsection{Goodness of Fit}

Berdasarkan perhitungan didapatkan hasil $R_{A d j, k}^{2}=0,58487$. Artinya produksi ikan dipengaruhi oleh jumlah nelayan, jumlah kapal, jumlah trip, jumlah unit penangkapan dan jumlah rumah tangga/perusahaan perikanan sebanyak 58,487\% dan sisanya 41,513\% dipengaruhi faktor yang lain. Sedangkan untuk nilai MSE sebesar 146877,6.

\subsubsection{Uji Asumsi}

\section{Uji Normalitas}

Nilai $\mathrm{D}=0,18516$ dan $p$-value $=0,000041667$

Kesimpulan : Pada taraf signifikansi 5\% residual tidak berdistribusi normal

\section{Multikolinearitas}

Tabel 3. Nilai VIF

\begin{tabular}{ccc}
\hline Variabel & VIF & Keterangan \\
\hline Jumlah nelayan & 3,3154 & VIF $<10$ \\
Jumlah kapal & 1,0031 & VIF $<10$ \\
Jumlah trip & 1,3252 & VIF $<10$ \\
Jumlah unit penangkapan & 3,2893 & VIF $<10$ \\
$\begin{array}{c}\text { Jumlah rumah } \\
\text { tangga/perusahaan } \\
\text { perikanan }\end{array}$ & 1,2986 & VIF $<10$ \\
pulan : Pada taraf signifikansi 5\% tidak terjadi multikolinieritas
\end{tabular}

Kesimpulan : Pada taraf signifikansi 5\% tidak terjadi multikolinieritas

\section{Uji Autokorelasi}

Nilai $d=2,2735$ dan $p$-value $=0,36011$

$4-d_{L}(1,3953) \leq d(2,2735) \leq 4$

Kesimpulan : Pada taraf signifikansi 5\%, terdapat autokorelasi antar residual. 


\section{Heteroskedastisitas}

Tabel 4. Tabel Uji Glejser

\begin{tabular}{cccc}
\hline Variabel & $\boldsymbol{t}_{\text {hitung }}$ & p-value & Keputusan \\
\hline Constant & 3,5934 & 0,00072 & $\mathrm{H}_{0}$ ditolak \\
Jumlah nelayan & $-1,5621$ & 0,12433 & $\mathrm{H}_{0}$ diterima \\
Jumlah kapal & 1,9563 & 0,05582 & $\mathrm{H}_{0}$ diterima \\
Jumlah trip & 2,5443 & 0,01396 & $\mathrm{H}_{0}$ ditolak \\
Jumlah unit penangkapan & 3,2753 & 0,00188 & $\mathrm{H}_{0}$ ditolak \\
Jumlah rumah & 0,96586 & 0,33859 & $\mathrm{H}_{0}$ diterima \\
tangga/perusahaan perikanan & &
\end{tabular}

Kesimpulan : Pada taraf signifikansi 5\%, terjadi heteroskedastisitas.

\subsection{Pendeteksian Pencilan}

Pendeteksian pencilan dilakukan dengan menggunakan DFFITS dan jumlah data (n) sebesar 58 termasuk gugus data besar, maka batas suatu data dikatakan sebagai pencilan jika nilai $\mid$ DFFITS $\mid>0,6432675$ dengan $p=6$. Ditemukan bahwa sebanyak 9 pencilan terdeteksi, yaitu data ke 4, 11, 29, 38, 39, 40, 42, 50, 56.

\subsection{Regresi Robust S-estimator}

Pada iterasi awal dalam regresi robust $S$-estimator digunakan nilai residual $\left(e_{i}\right)$ yang didapatkan dari hasil Regresi Linier Berganda dengan estimasi parameter menggunakan MKT.

\subsubsection{Estimasi Parameter Regresi}

Perhitungan dengan metode robust S-estimator didapatkan nilai estimasi parameter sebagai berikut :

\subsubsection{Uji Hipotesis}

$$
\hat{y}=36,032+0,0769 x_{1}+0,0387 x_{2}+0,000947 x_{3}+0,1215 x_{4}+0,000268 x_{5}
$$

\section{Uji F}

\section{a. Hipotesis}

$\mathrm{H}_{0}: \beta_{1}=\beta_{2}=\beta_{3}=\beta_{4}=\beta_{5}=0$

$\mathrm{H}_{1}$ : terdapat $\beta_{\mathrm{j}} \neq 0, \mathrm{j}=1,2,3,4,5$

b. Taraf signifikansi

$\alpha=5 \% \cong 0,05$

c. Statistik uji

$F_{\text {hitung }}=84,645$ dan $p$-value $=0,00000$

d. Kriteria uji

$\mathrm{H}_{0}$ ditolak jika $F_{\text {hitung }}>\left(F_{(5 \%, 5,52)}=2,39\right)$ atau $p$-value $<\alpha(0,05)$

\section{e. Keputusan}

$\mathrm{H}_{0}$ ditolak karena $p$-value $(0,00000)<\alpha(0,05)$

\section{f. Kesimpulan}

Pada taraf signifikansi 5\% terdapat hubungan antara variabel respon produksi ikan dengan variabel prediktor secara bersama-sama.

2. Uji t
a. Hipotesis
$\mathrm{H}_{0}: \beta_{\mathrm{j}}=0$, dimana $\mathrm{j}=1,2,3,4,5$
$\mathrm{H}_{1}: \beta_{\mathrm{j}} \neq 0$, dimana $\mathrm{j}=1,2,3,4,5$

b. Taraf signifikansi

$\alpha=5 \% \cong 0,05$

\section{c. Statistik uji \\ Disajikan pada Tabel 5.}




\section{d. Kriteria uji}

$\mathrm{H}_{0}$ ditolak jika $\left|t_{\text {hitung }}\right|>\left(t_{(2,5 \%, 52)}=2,00665\right)$ atau $p$-value $<\alpha(0,05)$

\section{e. Keputusan}

Tabel 5. Tabel Uji t Regresi Robust S-estimator

\begin{tabular}{cccc}
\hline Variabel & $\boldsymbol{t}_{\text {hitung }}$ & $\boldsymbol{p}$-value & Keputusan \\
\hline Constant & 1,2546 & 0,21525 & $\mathrm{H}_{0}$ diterima \\
Jumlah nelayan & 2,6549 & 0,01050 & $\mathrm{H}_{0}$ ditolak \\
Jumlah kapal & 2,3855 & 0,02073 & $\mathrm{H}_{0}$ ditolak \\
Jumlah trip & 8,6034 & 0,00000 & $\mathrm{H}_{0}$ ditolak \\
Jumlah unit penangkapan & 4,2174 & 0,00009 & $\mathrm{H}_{0}$ ditolak \\
Jumlah rumah & 1,1706 & 0,24709 & $\mathrm{H}_{0}$ diterima \\
tangga/perusahaan perikanan & & & \\
\hline
\end{tabular}

\section{f. Kesimpulan}

Pada taraf signifikansi 5\%, koefisien parameter variabel jumlah nelayan $\left(x_{1}\right)$, jumlah kapal $\left(x_{2}\right)$, jumlah trip $\left(x_{3}\right)$, dan jumlah unit penangkapan $\left(x_{4}\right)$ berpengaruh signifikan terhadap produksi ikan $(y)$.

\subsubsection{Goodness of Fit}

Berdasarkan perhitungan didapatkan hasil $R_{A d j, k}^{2}=0,88006$. Artinya produksi ikan dipengaruhi oleh jumlah nelayan, jumlah kapal, jumlah trip, jumlah unit penangkapan dan jumlah rumah tangga/perusahaan perikanan sebanyak 88,006\% dan sisanya $11,994 \%$ dipengaruhi faktor yang lain. Sedangkan nilai MSE sebesar 7109,519.

\subsection{Prosedur Penggunaan Aplikasi GUI Matlab}

Prosedur penggunaan program GUI Matlab untuk metode regresi robust S-estimator sebagai berikut:

1. Tampilan utama GUI Matlab pemodelan regresi robust $S$-estimator untuk penanganan pencilan.

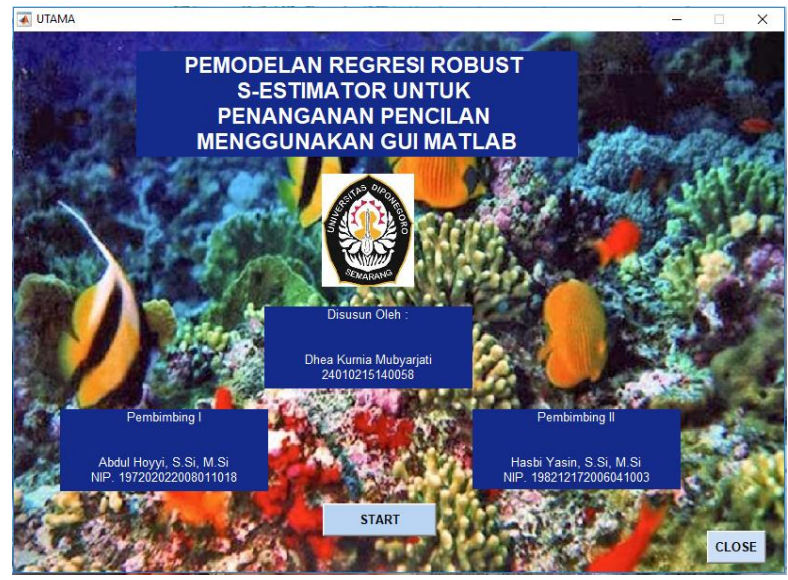

Gambar 1. Tampilan Utama GUI Matlab Perhitungan Regresi Robust S-estimator

2. Perhitungan pendeteksian pencilan dapat ditampilkan dengan melakukan klik pada tombol "Start". 


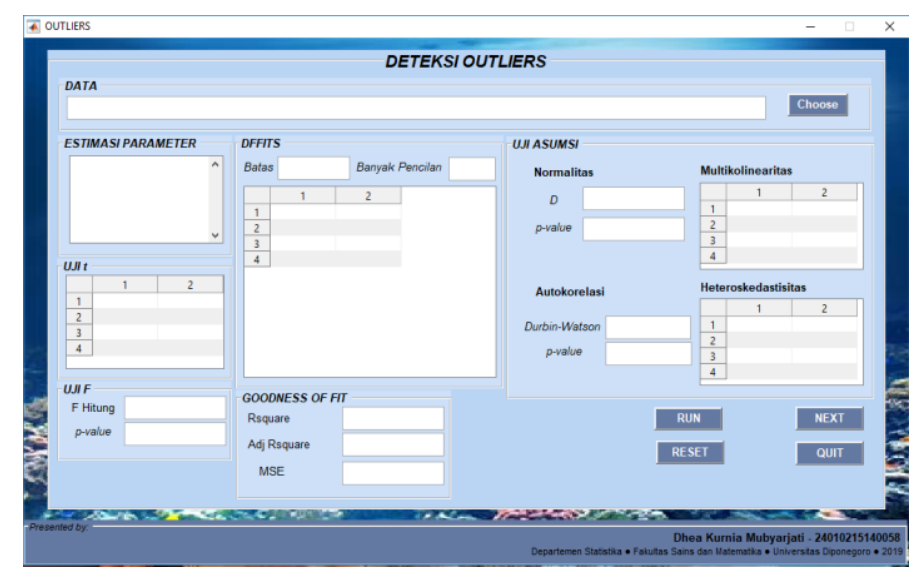

Gambar 2. Tampilan Hasil GUI Matlab Deteksi Outliers

3. Apabila akan dilanjutkan pada perhitungan regresi robust S-estimator maka klik tombol "Next".

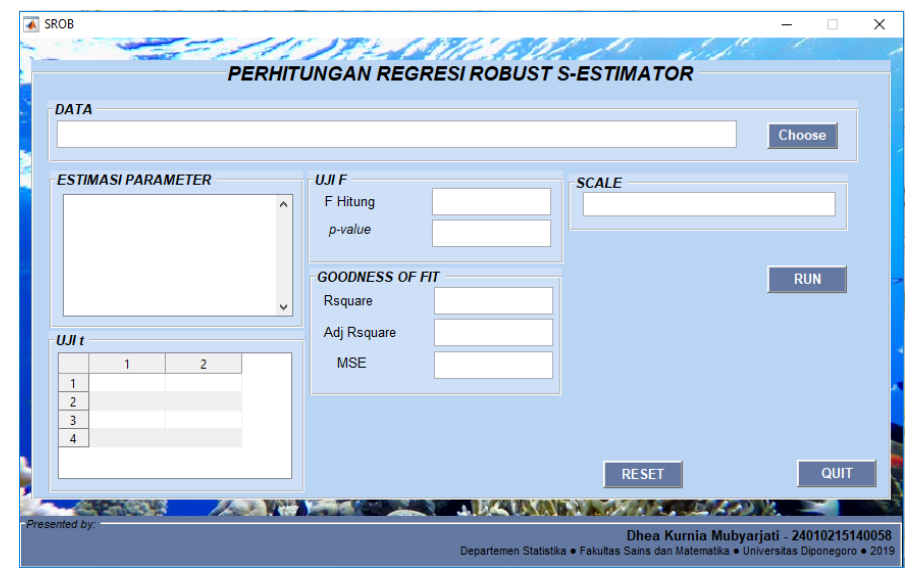

Gambar 3. Tampilan Hasil Perhitungan Regresi Robust S-Estimator

\section{KESIMPULAN}

\subsection{Kesimpulan}

Berdasarkan hasil dan pembahasan menggunakan estimasi parameter MKT dan robust dalam pemodelan produksi ikan tangkap di Jawa Tengah, diperoleh kesimpulan sebagai berikut :

1. Menggunakan estimasi parameter MKT diperoleh model regresi sebagai berikut : $\hat{y}=109,9-0,12089 x_{1}+0,088464 x_{2}+0,00175 x_{3}+0,2101 x_{4}+0,00099 x_{5}$

Berdasarkan uji t yang dilakukan terdapat dua variabel yang signifikan yaitu jumlah trip dan jumlah unit penangkapan. Selain itu terdapat 9 pencilan pada data. Oleh karena itu digunakan metode regresi robust S-estimator yang kekar terhadap pencilan.

2. Menggunakan estimasi parameter robust $S$-estimator diperoleh model sebagai berikut: $\hat{y}=36,032+0,0769 x_{1}+0,0387 x_{2}+0,000947 x_{3}+0,1215 x_{4}+0,000268 x_{5}$

3. Produksi ikan tangkap di Jawa Tengah dipengaruhi oleh jumlah nelayan, jumlah kapal, jumlah trip, jumlah unit penangkapan dan jumlah rumah tangga/perusahaan perikanan sebesar 88,006\% dan nilai MSE nya 7109,519.

\subsection{Saran}

Berdasarkan hasil penelitian ini diharapkan bagi Dinas Kelautan dan Perikanan Provinsi Jawa Tengah untuk dapat memberikan kebijakan mengenai penghimpunan data produksi ikan tangkap di masing-masing kabupaten/kota di Jawa Tengah sehingga data dapat lebih lengkap untuk setiap tahunnya. Selain itu penulis juga mengusulkan saran guna 
dilakukannya pengembangan dari penelitian ini yaitu dibuat komputasi GUI Matlab untuk estimator yang lainnya.

\section{DAFTAR PUSTAKA}

[BPS]. Badan Pusat Statistik Provinsi Jawa Tengah. https://jateng.bps.go.id/ (diunduh 03 Januari 2019).

[DKP]. Dinas Kelautan dan Perikanan Provinsi Jawa Tengah. 2016. STATISTIK PERIKANAN TANGKAP JAWA TENGAH, 2015. Semarang: Dinas Kelautan dan Perikanan Provinsi Jawa Tengah.

Chen, C., 2002. Robust Regression and Outlier Detection with The ROBUSTREG Procedure, paper 265-27. s.1.:SAS Institute Inc., Lary, NC.

Draper, N. R. \& Smith, H., 1998. Applied Regression Analysis. 3 ed. New York: John Wiley and Sons.

Fox, J., 2002. Robust Regression : Appendix to An $R$ and S-Plus Companion to Applied Regression.

Ghozali, I., 2011. Aplikasi Analisis Multivariate dengan Program IBM SPSS 19. Semarang: Badan Penerbit Universitas Diponegoro.

Gujarati, D. N., 2004. Basic Econometrics. 4 ed. New York: The Mc Graw-Hill Companies.

Hendra \& Amir, 2014. Taiwan Business Club Indonesia Tertarik Potensi Perikanan Jawa Tengah. [Online] Available at: http://www.pemudamaritim.com/2015/01/taiwanbusiness-club-indonesia-tertarik.html (Diakses 26 Desember 2018).

Maronna, R. A., Martin, R. D. \& Yohai, V. J., 2006. Robust Statistics Theory and Methods. New York: John Wiley and Sons, Ltd.

Montgomery, D. C. dan Peck, E. A. 1992. Introduction To Linier Regression Analysis. New York : John Wiley and Sons, Inc.

Montgomery, D. C. \& Runger, G. C., 2003. Applied Statistics and Probability for Engineers. 3 ed. United States od America: John Wiley and Sons.

Neter, J., Wasserman, W. \& Kutner, M. H., 1997. Model Linear Terapan. Bogor: Jurusan Statistika FMIPA-IPB.

Pusadan, M. Y., 2014. Pemrogaman Matlab pada Sistem Pakar Fuzzy. Yogyakarta: Deepublish.

Stuart, C., 2011. Robust Regression. England: Durham University.

Sugiharto, A., 2006. Pemrograman GUI dengan MATLAB. Yogyakarta: Andi.

Susanti, Y., 2014. M Estimation, S estimation, and MM Estimation In Robust Regression. International Journal of Pure and Applied Mathemathics, Volume 91, pp. 349-360. 